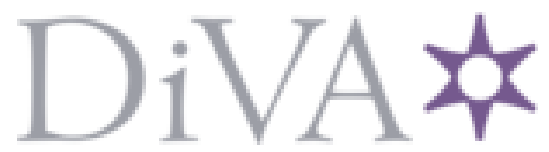

http://www.diva-portal.org

\title{
Postprint
}

This is the accepted version of a paper published in Industrial Marketing Management. This paper has been peer-reviewed but does not include the final publisher proof-corrections or journal pagination.

Citation for the original published paper (version of record):

Bengtsson, M., Raza-Ullah, T., Vanyushyn, V. (2016)

The coopetition paradox and tension: the moderating role of coopetition capability.

Industrial Marketing Management, 53: 19-30

https://doi.org/10.1016/j.indmarman.2015.11.008

Access to the published version may require subscription.

N.B. When citing this work, cite the original published paper.

Permanent link to this version:

http://urn.kb.se/resolve?urn=urn:nbn:se:umu:diva-116721 


\section{The coopetition paradox and tension: The moderating role of coopetition capability}

Maria Bengtsson $^{\mathrm{a},{ }^{*}}$, Tatbeeq Raza-Ullah ${ }^{\mathrm{a}, 1}$, Vladimir Vanyushyn ${ }^{\mathrm{a}, 2}$

${ }^{\mathrm{a}}$ Umeå School of Business and Economic, Umeå University, S-901 87 Umeå, Sweden

* Corresponding author. Tel.: +4690786 6161; fax: +46907867764.

E-mail addresses: maria.bengtsson@usbe.umu.se (M. Bengtsson), tatbeeq.raza@usbe.umu.se (T. Razaullah), vladimir.vanyushyn@usbe.umu.se (V. Vanyushyn).

${ }^{1}$ Tel.: +46907865287.

${ }^{2}$ Tel.: +46907865287 


\title{
Coopetition paradox and tension: The moderating role of coopetition capability
}

\begin{abstract}
In this study, we apply a paradox perspective on coopetition to investigate the effects of coopetition paradox on managers' experience and perception of coopetitive tensions, and the role of coopetition capability in managing such tensions. We propose a theoretical model to posit that the intensity of coopetition paradox positively associates with managers' experience of external tension, which in turn lead them to perceive internal tension. Further, coopetition capability plays a dual role-moderates the relation between coopetition paradox and external tension, and reduces internal tension. We tested hypotheses on a representative multi-industry sample of 1532 firms in Sweden and the results confirm them. Our study contributes to understanding the critical role of coopetition capability that enables firms to maintain a moderate level of tension regardless of the intensity of coopetition paradox.
\end{abstract}

Key words: Coopetition, paradox, tension, coopetition capability. 


\section{Introduction}

The engagement of firms in coopetition, defined as simultaneous pursuit of cooperation and competition between firms (Lado, Boyd \& Hanlon, 1997; Bengtsson \& Kock, 2000; Padula \& Dagnino, 2007; Yami, Castaldo, Dagnino \& Le Roy, 2010), materializes a paradox in the relationship (Raza-Ullah, Bengtsson \& Kock, 2014; Fernandez, Le Roy \& Gnyawali, 2014). Scholars argue that such a paradox translate into tensions that in turn have the potential to aggravate the relationship and break partnerships (Das \& Teng, 2000; Fang, Chang \& Peng, 2011). Huge failure rates of alliances between competitors (Lunnan \& Haugland, 2008; Park \& Ungson, 2001) indicate that firms lack the required capability to manage coopetitive tension. We name this specific capability as coopetition capability. Except for a few theoretical and anecdotal accounts concerning this capability (Gnyawali, Madhavan, He \& Bengtsson, 2012; Gnyawali \& Park, 2011; Raza-Ullah \& Bengtsson, 2014), there has hardly been any detailed empirical investigation on how coopetition capability can help firms deal with the coopetition paradox and the resultant tension. We address this gap by examining how the strength of the coopetition paradox results in different degrees of external and subsequently internal tension, and the critical role of coopetition capability moderating external tension formation and reducing the internal tension.

We argue that as the potency of coopetition paradox can range from strong to weak (Park, Srivastava \& Gnyawali, 2014; Raza-Ullah et. al, 2014), the resultant tension also varies accordingly and in turn impacts the desired outcomes. Prevailing views however, mainly consider managing the paradox (e.g., Bengtsson, Eriksson \& Wincent, 2010) and overlook managing the resultant tensions. Apparently, focal firm's managers may not exercise much control to manage (or balance) the coopetition paradox per se, as several macro forces such as demands in industries, network dynamics, and third party influence often prescribe the degree of cooperation and competition (e.g., Garud \& Kumaraswamy, 1995; Miriani, 2007; Wu. Choi \& Rungtusanatham 2010). However, they can manage the tension that a strong (or weak) paradox creates for them and other employees in the focal firm. Despite several calls made to empirically investigate the management of tension (e.g., Gnyawali et al., 2012) and this special issue call, "a closer examination of ways of managing tension is thus critical to develop a theory of coopetition" (p.1), we still lack a rigorous examination of the capability required to manage tension. Based on the notion that a moderate level of tension is beneficial in coopetition (Park et al., 2014; Raza-Ullah \& Bengtsson, 2014), we define coopetition capability as the ability to think paradoxically and to initiate processes that help firms attain and maintain a moderate level of tension, irrespective of the strength of the paradox.

Coopetition capability is a must-have competence of top managers for two key reasons. One, they experience coopetitive tension as they are directly involved in both cooperation and competition activities and thus need coopetition capability to manage tension effectively. We name this coopetitive tension arising from the paradox and experienced directly by top managers as external tension. Two, top-level managers need to be capable enough to prevent the spillover of external tension inside the firm. This is critical because lower level employees are not usually involved in coopetition-related decisions and might not understand the necessity of different strategic moves and counter moves, or lack coopetition capability to handle external tension. Thus, a spillover of external tension into the organization would therefore have negative effects. We call the tension that is spread internally and experienced by the lower levels as internal tension.

We derive a set of hypotheses based on our theoretical discussion. The empirical analysis builds on a representative multi-industry survey of 1532 Swedish firms administered by the Swedish National Bureau of Statistics 2013. Overall, the results show that there is a significant direct relation between the strength of coopetition paradox and external tension, 
and coopetition capability provides a strong moderating effect on this relationship. Moreover, the results indicate that managers' experience of external tension leads them to become aware of the internal tension and their coopetition capability helps reduce the perceived internal tension. This is important, as top managers are often responsible for managing and balancing the internal tension (c.f. Lubatkin, Simsek, Ling \& Veiga, 2006). Further, coopetition capability stands out to be distinct from other general capabilities like network and absorptive capabilities, which implies that it is a specific capability needed in unique paradoxical coopetitive relationships between firms.

Our main contributions are threefold. First, we contribute to the coopetition literature by showing that coopetition paradox results in coopetitive tension, which further suggests that paradox and tension are distinct concepts. Second, we suggest that coopetition capability moderates the link between coopetition paradox and tension, and thus enables firms to attain and maintain tension on a moderate level irrespective of the strength of coopetition paradox. Third, we provide evidence that coopetition capability affects how managers perceive the internal tension that prevails at the lower levels within the firm. Overall, we contribute by illustrating that coopetition capability plays a critical role in dealing with both external and internal tension.

\section{Coopetition paradox, tension and coopetition capabilities}

Three elements are critical to the research questions examined in this article: the coopetition paradox, coopetitive tension, and coopetition capability. In this section we will define and discuss the nature of these three elements.

\subsection{Coopetition paradox}

Coopetition entails simultaneous pursuit of cooperation and competition between a pair of firms (Bengtsson \& Kock, 2000, Gnyawali \& Park, 2011) often in the form of a strategic alliance or a joint venture, and is argued to be a win-win strategy (Brandenburger \& Nalebuff, 1996). Literature lists numerous drivers and positive outcomes of coopetition such as: to improve quality standards, production efficiency, and product innovation; to influence a third party; to achieve economies of scope; and setting industry standards, among others (Gnyawali \& Park, 2011; Luo, 2007). Presumably, coopetition can bring advantages of both cooperation and competition or "coopetitive advantage" (Dagnino \& Padula, 2002), however, the nature of coopetition is complex and it could result in a lose-lose situation. For instance, the FordVolkswagen alliance set up in 1980s could not outcompete its major competitor GM because both partners were direct competitors and managers were not willing to share their marketing strategies and design skills with each other (cf. Park \& Ungson, 2001). Although a strong competitor is considered to be the best partner in a strategic alliance (Deming, 1993), which explains why more than 50 percent of all new alliances are formed between already competing firms (Harbison \& Pekar, 1998), yet more than half of all strategic alliances fail (Lunnen \& Haugland, 2008; Park \& Ungson, 2001). These findings show that coopetition is a challenging phenomenon that must be managed effectively.

However, the first step before discussing how to manage coopetition is to understand what coopetition is, i.e., to understand the nature of the phenomenon. Coopetition is paradoxical as it involves firms interacting with two contradictory logics - cooperation and competition. Whereas cooperation underscores mutual benefits and collective interests, competition emphasizes opportunistic behavior and private interests (Khanna, Gulati \& Nohria, 1998; Park \& Zhou, 2005). These logics are not easy to reconcile, yet the relationship involves their simultaneous presence. The word 'simultaneous' is the crux of coopetition. 
Cooperating during one period and competing in another would simply mean cooperation or competition in isolation and that would negate the definition of coopetition (cf. Luo, 2007). Whereas simply cooperating with a partner, or solely competing with a rival makes more sense, juxtaposing cooperation with competition makes coopetition irrational, inconsistent and even absurd. Scholars name such a phenomenon as a paradox that relates to "contradictory yet interrelated elements (dualities) that exist simultaneously and persist over time; such elements seem logical when considered in isolation, but irrational, inconsistent, and absurd when juxtaposed" (Smith \& Lewis, 2011; 387). Thus coopetition is a paradox (and not simply a trade-off between cooperation and competition) that juxtaposes the contradicting dualities of cooperation and competition.

That coopetition is a paradox also justifies that it occurs on two continua in contrast to one continuum where competition increases at the expense of cooperation and vice versa (Bengtsson et al., 2010). On two continua, both competition and cooperation can vary from low to high intensities such that coopetition paradox can be both balanced (strong and weak) and unbalanced (cooperation or competition dominated). As Figure 1 illustrates, coopetition paradox is balanced-strong (or balanced-weak) when the intensities of both cooperation and competition are simultaneously high (or low) along the balanced curve. Thus the paradoxical nature of coopetition makes it clear that coopetition must be understood and conceptualized on two continua. Further, the paradox is unbalanced if the intensity level of either cooperation or competition exceeds the other. In other words, the paradox is either cooperation-dominated or competition-dominated but not balanced. Previous research on coopetition suggests that a balanced coopetition paradox is beneficial for performance (Bengtsson et al., 2010; Park et al., 2014; Raza-Ullah et al., 2014). Furthermore both cooperation and competition need to be reasonably balanced. Scholars argue that "[w]ithout adequate cooperation, alliances cannot be operated smoothly. Without sufficient attention to competition, alliances will unwittingly lose their competitive advantage and equitable rights and rewards. Both cooperation and competition must be preserved in an alliance as dynamic and permanent conditions." (Das \& Teng, 1999: 59). Thus when the forces to cooperate and to compete are neither too strong nor too weak and reasonably balanced firms can create coopetition advantages (Dagnino \& Padula, 2002).

Figure 1 about here

\subsection{Coopetitive tension}

The very nature of the paradox engenders tension (e.g., Lewis, 2000; Poole \& Van de Ven, 1989). Tension results from the coopetition paradox and is felt when managers involved in coopetition pursue "two co-existing contradictory forces with conflicting goals." (Fang et al., 2011: 774). Coopetitive tension differs from other non-paradoxical and normal tensions in organizational life. For instance, loosing key employees or key customers to a major competitor (i.e., only competitive relationship) give rise to tension that is filled with negative feelings (i.e., competitive tension). Coopetitive tension, however, originates from the paradox and involves both negative and positive feelings such as simultaneously trusting and distrusting the coopetition partner (c.f. Lewicki, McAllister \& Bies, 1998; Raza-Ullah et. al, 2014). Thus, managers experiencing coopetitive tension feel torn between the simultaneous and contradictory demands of cooperation and competition.

Researchers have recently recognized different sources of tension in coopetition (Fernandez et al, 2014; Tidström, 2014). Considering the sources of tension at different levels 
(Fernandez et al., 2014), we distinguish between external and internal tension. First, external tension refers to the level of difficulty managers at the top levels experience when they engage with the other firm in both cooperation and competition activities. For instance, managers find it difficult to work together with the competitor to create value while simultaneously competing to seize the maximum share of the value created (Brandenburger \& Nalebuff, 1996). Another difficulty can arise when managers find it difficult to create a balance between sharing and protecting knowledge. For instance, R\&D alliances between competitors challenge the "partner firms to find means to obtain the appropriate balance between knowledge sharing and knowledge protection." (Li, Eden, Hitt, Ireland \& Garrette, 2012: p.1191). Further, as the two firms are distinct entities with different cultures and conflicting economic interests, the level of difficulty to work together closely increases. Consequently the managers involved would experience what we call external tension.

Second, internal tension refers to the tension experienced by lower levels in the organization. Prior research acknowledges the prevalence of internal coopetitionsimultaneous cooperation and competition between units or departments within the firm (Fernandez et al., 2014; Luo, Slotegraaf, \& Pan, 2006; Tsai, 2002)-yet little is known about internal tension (Näsholm \& Bengtsson, 2014). In this study, we argue that one critical but overlooked implication of external tension is that units within the focal firm have different and sometimes conflicting opinions, in contrast to top-level managers, on the value of cooperating with a competitor. This further causes frustration and tension inside the organization, as strategic decisions made by senior managers are not always understood at lower levels creating both positive and negative feelings for them.

Consider the coopetitive relationship between Ericsson and Oracle to envisage the existence of internal tension inside Ericsson - the focal firm in that case (Bengtsson \& Johansson, 2014). Sun Microsystem was Ericsson's best partner providing them with operation systems and software. However, Ericsson supported Oracle (despite being its fierce competitor) to acquire Sun Microsystem. The rationale behind this strategic move was twofold. One, Oracle could help Sun to recover from its bad financial standings, and two, it was possible to avoid its acquisition by alternate buyers like IBM. The top management of Ericsson considered it a good strategic move compared to other available solutions. However, different units inside Ericsson that mainly competed or cooperated with Oracle/Sun felt internal tensions. For instance, the engineers working with Sun in product and development projects found it difficult to understand why Ericsson had to support a fierce rival to acquire its best partner. These conflicting values between top and lower levels created tension within the organization (i.e., internal tension).

\subsection{The concept of coopetition capability.}

Despite huge failure rates of paradoxical coopetitive relationships, empirical studies investigating the management of coopetitive tensions are scant. The prevailing views on managing coopetition have typically offered structural strategies that suggest separating cooperation and competition in time, space or between levels (Bengtsson \& Kock, 2000; Dowling Roering, Carlin \& Wisnieski 1996; Oliver, 2004). The argument is that tension, by default, is unpropitious and harmful and should either be avoided or eliminated. Structural strategies however carry one major limitation. Even if cooperation and competition are separated between units or departments or between levels, the top managers still have to integrate and coordinate their contradictory demands at higher levels (Eisenhardt, Furr \& Bingham, 2010) and will experience tension. Scholars have also proposed an integration approach to manage paradoxes (e.g., Fernandez et al., 2014; Smith \& Lewis, 2011) Integration strategies are needed to address the both/and nature of a paradox (Gibson \& 
Birkinshaw, 2004). However, integration would likely increase the intensity of tension as the contradictions become more salient when they are juxtaposed. Thus managers would still need specific capability to manage the resultant tension.

More recently, scholars have pointed toward different levels of external tensions that are associated with positive and negative consequences. They propose that tension is not always bad and doesn't necessarily need to be avoided or eliminated, rather it is an inevitable part of a paradoxical relationship that must exist, up to a moderate level, to build necessary and sufficient pressure to fuel coopetitive performance (Raza-Ullah \& Bengtsson, 2014). Further, levels of coopetitive tension that are too low or too high would likely bring negative results and therefore need to be achieved on a moderate level (Gnyawali et. al, 2012; Raza-Ullah \& Bengtsson, 2014). Thus on one hand, avoiding or eliminating tension (i.e. structural approach) might not be a successful strategy as tension can become too weak, and on the other hand, integration carries with it a strong tension. Therefore certain specific capabilities that enable firms to integrate contradictions yet keep the tension on a moderate level are required in addition to structural and integration strategies.

The current literature on inter-firm relationships mainly refers to general capabilities such as alliance capability (c.f. Wang \& Rajagopalan, 2015) and network capability (c.f. Walter, Auer \& Ritter, 2006) to manage these relationships, and lacks insights on how to deal with coopetition paradox and the coopetitive tensions discussed above. General capabilities are important in managing the overall inter-firm relationship, but need to be complemented by coopetition capability as the latter significantly differs from the former. Coopetition capability is distinct because it is tailored to manage the contradicting dualities, demands, or logics of interactions pursued simultaneously, as well as the level of difficulty (or tension) experienced by managers as a result of coopetition.

Coopetition literature mentions some of the capabilities needed to manage the relationship and the resultant tension. For example, Gnyawali and Park (2011), based on a case study of coopetition between Sony and Samsung, suggest three main capabilities that are critical to manage the paradoxical relationship. Whereas the first two capabilities, coopetition experience and mindset of executives, enable firms to handle conflicts and tensions, the third, superior and complementary resources helps firms to develop their relationship in a more balanced way. Similarly, Gnyawali et. al (2012) propose analytical and executional capabilities to manage coopetition and the resultant tensions. The former refers to the ability to create a clear and precise understanding of the paradoxical situation. It allows managers to understand why it is advantageous to cooperate and compete simultaneously. The latter refers to the development, implementation, and utilization of routines in the firm. It specifically helps the firm to balance the conflicting demands without jeopardizing the desired objectives by developing a repertoire of alternative strategies that can be used (c.f. Eisenhardt et al., 2010). More recently, scholars have also leveraged insights from ambidexterity literature to propose that specific ambidextrous skills are needed to manage coopetitive tensions (Fernandez et. al, 2014; Raza-Ullah \& Bengtsson, 2013). Although coopetition literature proposes different kinds of capabilities required to manage the tensions, we still lack an empirically validated definition of the concept of coopetition capability. In this article we define, advance, and test the concept of coopetition capability to enable an empirical investigation of how firm's coopetition capability affects the managers in more, or less, intense coopetitive relationships.

The concept of coopetition capability is perhaps best understood as an analog to the concept of ambidexterity. Capabilities mentioned in coopetition literature may well be necessary conditions to effectively manage coopetitive tensions; we argue that ambidexterity must certainly be the fundamental condition defining the concept (c.f. Im \& Rai 2008; Lin, Yang \& Demirkan, 2007). We integrate critical capabilities referred to in coopetition 
literature with the core underpinnings of ambidexterity literature to develop and advance the concept of coopetition capability. Ambidexterity refers to the ability of an organization to simultaneously pursue and balance seemingly contradictory demands such as exploration and exploitation (Gibson \& Birkinshaw, 2004). Scholars put a great emphasis on managers' ambidexterity to deal with conflicts (Duncan, 1976; Floyd \& Lane, 2000; Mom, Bosch \& Volberda, 2009; Smith \& Tushman, 2005). Ambidexterity helps managers to host contradictions; fulfill multiple and conflicting roles and tasks; and refine and renew their skills and expertise according to the situation (Mom et. al., 2009). Ambidexterity literature usually addresses the competing tensions that take place inside the organization. In other words, it mainly discusses the management of internal tensions. In the context of coopetition paradox, managers deal with both internal and external tensions, and thus need to be even more ambidextrous when dealing with both kinds of tensions.

Ambidextrous managers engage in paradoxical thinking by "exploring the tension in a creative way that captures both extremes" rather than performing a simple either/or trade-off (Eisenhardt, 2000: 703). Denison, Hooijberg \& Quinn (1995) argue that managers need cognitive complexity that enables them to hold two contradicting ideas in their mind and still retain the ability to make decisions and act in paradoxical situations. They argue that managers need to develop behavior repertoires to respond appropriately to contradicting demands that may require contrary or opposing actions. Moreover, Eisenhardt et al. (2010) discuss the role of ambidextrous thinking and argue that managers should devote attention to and integrate contradictory cognitive agendas to better allocate resources. They argue that abstract thinking, cognitive variety, and interruption create more flexible strategic thinking enabling firms to accommodate coexisting and contradicting cognitive agendas (Brown and Eisenhardt, 1997). Abstract thinking is linked to a firm's understanding of the situation. By abstraction it is possible to develop a unified understanding that enables firms to act appropriately in different situations. The cognitive variety makes it possible for firms to develop a larger repertoire of strategies that can be applied simultaneously. Interruption or the reassessment and redirection of strategies make it possible to change and adapt to new demands.

Building on the core underpinnings of literature on ambidexterity (Eisenhardt et al., 2010; Gibson \& Birkinshaw, 2004; Mom et. al, 2009) and coopetition (Gnyawali \& Park, 2011; Gnyawali et. al., 2012) we define the concept of coopetition capability as the ability to think paradoxically and to initiate processes that help firms attain and maintain a moderate level of tension, irrespective of the strength of the paradox. The paradoxical thinking refers to understanding, accommodating and responding well to the contradictory demands of coopetition. It involves coopetition mindset and experience (Gnyawali \& Park, 2011), analytical capability (Gnyawali et. al, 2012), as well as the cognitive complexity to hold contradictions in mind while still retaining the ability to function effectively (Denison et. al, 1995). Initiate processes refer to the development of processes, routines, and a culture that allow managers to act in dynamic ways to keep the tension at a moderate level to function well. These processes and routines facilitate managers to reconfigure activities and quickly meet the changing demands (Gibson \& Birkinshaw, 2004) of the relationship. Further, they provide enough room for managers to develop a repertoire of alternative strategies as well as to change the scope and content of the relationship (Eisenhart et al., 2010; Mom et. al, 2009). These processes also support managers to execute their capability (Gnyawali et. al, 2012) in balancing contradictory demands without jeopardizing the coopetition objectives.

\section{Theoretical model and hypothesis}


This section first applies the paradox perspective to coopetition to examine how the strength of the coopetition paradox affects managers' experience of external tension and their perception of internal tension. It then investigates how coopetition capability moderates the relationship between coopetition paradox and external tension and how it effects manager's perception of internal tension. Our theoretical model presented in Fig. 2 summarizes our key constructs (discussed in the previous section) and a set of hypotheses concerning their relations.

Figure 2 about here

\subsection{Coopetition paradox and tensions}

It is critical to determine the intensity of experienced tension as both too high and too low levels can have negative effects on the desired outcomes of the relationship (Park et al., 2014). We propose that the intensity of tension is contingent on the strength of the coopetition paradox in three different ways. First, managers that are involved extensively in both cooperation and competition will feel torn apart between the high demands of both contradictions, and might become paralyzed and indecisive (c.f. Raza-Ullah \& Bengtsson, 2014: Stratton, 2005). The difficulty increases and thus also the tension when managers have to keep a balance between simultaneous high contradictory demands. Thus a balanced-strong coopetition paradox will likely engender high levels of tension.

Second, and in contrast, if the intensities of both cooperation and competition are low, the relationship is more like trivial transactions in which the firms are neither involved in active moves and countermoves, nor share extensive knowledge and resources. In the case of such a balanced-weak paradox, the managers are less passionate as they cooperate little with the other firm and thus the threats of knowledge spillover and cheating are minimal. As a result they feel little tension. In addition, if one of the demands is extremely intense while the other is extremely weak, (competition-dominated and cooperation dominated paradoxes) managers will also experience low tension. This is because the degree of torness will be less, and instead of balancing the demands, managers would tend to tip toward the stronger demand while ignoring the weaker. This is an easy task rather than being difficult, as managers are not making cognitive efforts to balance the demands. Therefore, a weak coopetition paradox will likely engender low levels of tension. Third, if the coopetition paradox is reasonably balanced (i.e., neither extremely strong nor extremely weak) with adequate cooperation and sufficient competition (Das \& Teng, 1999), the tension felt will be moderate. This reasoning motivates the following hypotheses.

Hypothesis 1: The strength of coopetition paradox has a positive effect on managers' experience of external tensions

In addition, the external tension might spread into lower levels of the organization and create internal tensions. Employees and organizational units of a firm involved in a coopetitive relationship are likely to be aware of the existence of such relationship and the tensions that stem from it. The fact that their firm is cooperating with an entity that is commonly viewed as adversary (alternatively, taking competitive actions against an ally) might result in the firm's members forming varying opinions regarding the value of such relationship and experiencing frustration. In addition, these members might not have the full picture and understanding of the firm's involvement in coopetition as cooperation and 
competitions are often separated between units (Dowling et al., 1996; Oliver, 2004). As top managers are involved in both cooperation and competition activities (and experience tension) they can also see how this tension can spill-over and create internal tensions. Therefore, we propose that managers' experience of external tension enables them to perceive the tensions that exist at the lower levels in the organization. Accordingly we suggest the following hypothesis.

Hypothesis 2: Managers' experience of external tension has a positive effect on their perception of internal tension

\subsection{Tensions and managers' coopetition capability}

As discussed before, a moderate level of tension benefits the firm the most. Two natural questions emerge: (i) do these relationships come in a balanced form, and (ii) if not, how can a moderate level of tension be attained? In practice the likelihood of having a balanced coopetition relationship is very slim. First, weak tension is either engendered from low intensity in cooperation and competition, or from extremely unbalanced paradoxes. In general, fierce and strong competitor firms are not willing to take the risk of extensive cooperation as the danger to potentially exploit each other is high and cooperation can therefore be kept at an extremely low level. Coopetitive tension is weak because firms vigorously compete but indulge only in a fraction of cooperation activities. This hinders knowledge creation and exploration (Bengtsson, et al., 2010) because of the difficulty of devoting enough attention to the collaborative part of the relationship. In addition, coopetitive tension is also weak when firms are mainly concerned with strong collaborative objectives and ignore the possibilities of potential gains from competition. In other words, excessive commitment to each other, in face of limited competition, can result in over-embeddedness (c.f. Uzzi, 1997), which stimulates groupthink (cf. Pouder \& St. John, 1996). Thus, weak coopetitive tension jeopardizes coopetition objectives. Second, when both forces of cooperation and competition are very strong, managers will experience high levels of tension because they feel torn by extensive cooperation with a strong and a fierce rival. If the tensions become too strong the coopetition objectives will also be jeopardized.

We argue that in firms, which fail to achieve the desired outcomes under low and high levels of tension, the managers either lack, or only possess lower, levels of coopetition capability to manage these tensions. Coopetition capability enables managers to bring the extreme high or low levels of tensions to a moderate level in order to obtain fruitful benefits from coopetition regardless of the strength of the coopetition paradox. These managers can deal with both high and low tensions in a constructive manner as they can utilize their paradoxical thinking to reduce the higher levels of coopetitive tension that might cause managers to become ambivalent or indecisive (c.f. Raza-Ullah \& Bengtsson, 2014; Stratton, 2005). Thus, paradoxical thinking brings down the high levels of tension to a moderate level, retaining sufficient pressure to accommodate simultaneous contradicting demands in their minds, while still functioning effectively. They can also use the context and routines to escalate the lower levels of tensions, from an unbalanced coopetition relationship, to a reasonably balanced level by changing the scope and content of the relationship. Taken together, these arguments suggest that coopetition capability will moderate the relationship between coopetition paradox and external tension experienced by the managers. Hence, we formulate the moderation hypothesis as follows: 
Hypothesis 3: Coopetition capability moderates the relationship between coopetition paradox and external tension, such that firms with high levels of coopetition capability will report a moderate level of external tension, irrespective of the strength of the paradox

In addition, it is also critical for the top managers or executives to exercise their coopetition capability in dealing with the internal tension. In line with the literature suggesting that firms tend to avoid having lower levels and units engage in simultaneous pursuit of contradictions (Ambos, Mäkelä, Birkinshaw \& D'Este, 2008; Andriopoulos \& Lewis, 2008), and rather consider it is managers at the top who coordinate and integrate the spatially or temporally separated units (Cameli \& Halevi, 2009; Helfat \& Winter, 2011), we assume that internal tension is not desirable and beneficial, and thus needs to be reduced. We further propose that managers' coopetition capability helps the firm to reduce the internal tension in several ways. First, top managers decrease the level of competition between units by allocating less-negotiable resources to each unit (e.g., Eisenhardt et. al., 2010; He \& Wong, 2004). As a result the units focus more on either the cooperation side or on the competition side, and feel less tension. Second, the internal tension that develops as a result of conflicting opinions about the value of cooperation with a competitor, between the top management level and the lower levels, can be reduced by initiating an effective top-down communication. For instance, the Ericsson and Oracle/Sun coopetition example demonstrates that whereas the top managers (possessing coopetition capability) understood the advantages of helping Oracle to buy Sun, the lower-levels were unable to grasp the situation and felt tension. Thus it is critical for managers to effectively communicate the strategic moves taken by them to lower levels in order to reduce the frustration and tension inside the organization. However if managers lack higher levels of coopetition capability and do not have a clear understanding of the situation themselves, the internal tension will increase. Therefore, the importance of coopetition capability increases when the internal tensions increase. This leads us to our final hypothesis.

Hypothesis 4: Higher levels of coopetition capability are associated with lower levels of internal tension, irrespective of the strength of the paradox

\subsection{Covariates}

Our research aims at identifying unique effects of coopetition paradox on tensions and the moderating role of coopetition capability in such tension development. We therefore consider several control variables that might affect the formation of external and internal tension. Below we briefly present rationales for including those control variables, broadly grouped into inter-firm capabilities and firm characteristics.

Inter-firm capabilities. Given that coopetition is a paradox and thus unique, the general inter-firm capabilities such as alliance and networking capabilities (as mentioned before) might not be appropriate or sufficient to manage this unique phenomenon and the resultant tensions. A counter argument however could be that coopetition is a sub-set of a more general inter-firm relationship, and therefore one might assume that the tensions emerging from such coopetition might be affected by generic capabilities and competences. Therefore we control for the networking and absorptive capabilities to see if coopetition capability is distinct from these generic capabilities. First, networking capability (c.f. Walter, et al., 2006) builds on alliance capability research and focuses on the initiation, maintenance, and utilization of external relationships. It incorporates elements such as partner selection, negotiating the contract, coordination, relational skills, partner knowledge, and internal communication (see Wang \& Rajagopalan 2015 for a review), and further adds a learning perspective to the construct. Second, absorptive capacity can be described as the recognition, assimilation and 
application of valuable external knowledge for commercial purposes (Cohen \& Levinthal, 1990) and, as such, refers to inter-organizational learning. Coopetition scholars argue that firms need to possess absorptive capacity to gain new knowledge from external sources (Ritala \& Hurmelinna-Laukkanen, 2013).

Firm Characteristics. In our research model we account for firm heterogeneity by including firm size, industry affiliation and localization as controls. Firm size is a broad proxy for firm's available resources and organizational complexity (Camison-Zornoza, LapiedraAlcami, Segarra-Cipres \& Boronat-Navarro, 2004), factors that can affect tension formation. Industry affiliation of a firm is a proxy that allows accounting for a range of firm-level effects (Dess, Ireland \& Hitt, 1990) and seems particularly relevant in a coopetition context. Lastly, we include firm localization to account for variation in geographical density of firm population in Sweden, the context of the study. The geographical proximity is relevant in formation of local relationships and collaboration for innovation (e.g. Gertler, Wolfe \& Garkut, 2000).

\section{Study design and methodology}

\subsection{Population, sample and non-response bias assessment}

The data for the study comes from a survey distributed to 5000 Swedish firms stratified by region, firm size and industry affiliation. All firms with 250 to 499 employees were included in the sample, and a simple random sample was drawn from firms with 10-249 employees. The following industries were included according to Swedish Standard Industrial Classification 2007: Agriculture, forestry and fishing; Mining and quarrying; Manufacturing; Electricity, gas, steam and air conditioning supply; Water supply, sewerage, waste management and remediation activities; Construction; Transportation and storage; Accommodation and food service activities; Information and communication; Professional, scientific and technical activities; Administrative and support service activities; Human health and social work activities.

Given a large geographical variation in firm density in Sweden, a sample of 2500 firms was drawn from the regions that are classified as sparsely populated according to EU Nomenclature of Territorial Units for Statistics division (Northern Sweden). A further sample of 2500 firms was drawn from other parts of the country (East and South Sweden).

Table 1 about here

Table 1 describes the population and sampling approach. The survey was administered by the Swedish National Bureau of Statistics (SCB) ${ }^{3}$ and conducted from May to October, 2013. After two reminders, a total of 1532 complete responses were obtained, corresponding to $30.64 \%$ as a response rate. Table 2 reports the sample composition and response rate by industry and localization. The pattern of responses does not give any grounds for suspecting the non-response bias to be of a concern.

\footnotetext{
3 The data collection process was driven by two concerns: (1) Ensuring that only CEOs responded to the questions and (2) minimizing effort and costs on the part of the responding firms. That was to be ensured via consultations with the Board of Swedish Industry and Commerce for Better Regulation (Näringslivets Regelnämnd, NNR). Some of the established multiple-item scales had to be abridged in order to meet the reasonable workload requirement.
} 
Table 2 about here

\subsection{Survey development and measurement}

The independent variable in our model, coopetition paradox, is operationalized in an index that captures the intensity of both cooperation and competition. The other three core constructs are operationalized with multiple-item, 5-point, perceptual measurement scales. The measurement items for all the constructs are listed in Table 3.

Coopetition paradox (PDX). We constructed the multiplicative paradox intensity measure $P D X$ by multiplying two variables pertaining to (1) cooperation intensity aspect To what extent do you cooperate with your competitors? and (2) competition intensity aspect To what extent are you taking competitive actions against your competitors? Hence, we specify the intensity dimension of coopetition paradox $P D X$ as an increasing function of both cooperative and competitive aspects, in line with earlier studies and specifications (e.g. Luo et al., 2006). The multiplicative nature of the intensity dimension (between cooperation intensity and coopetition intensity) results in paradox intensity increases if either or both of the terms increase. To exemplify, those firms that cooperate and compete to a very large extent (e.g., 4 or 5 on both scales) experience a more intense coopetition paradox than firms that do not cooperate much and equally do not compete much (e.g., 1 or 2 on the scales).

Scale items of three variables in the model - external tension (ET), internal tensions (IT) and coopetition capability $(C C)$ - were developed based on previous research on paradoxical tension and ambidexterity following DeVellis's (1991) procedure prescription. New scales were needed as tension and capability in a coopetition context has not been studied quantitatively in previous studies. To assess the content validity of the scale items, experts evaluated the measurement items. A panel of 10 firms and six faculty members was asked to assess face validity of the constructs, similar to the validity check in $\mathrm{Wu}$, et al., (2010). They were given the nominal definition and were asked to provide suggestions on semantic changes and we presented our operational definition and asked them to recommend which items to include in the questionnaire. Finally, scale items were shown to two senior managers in one large Swedish manufacturing firm for evaluation and suggestions. The process resulted in the retention of four items for external tension, two items for internal tension, and four items for coopetition capability, provided in Table 3 . The operational definitions of the three constructs are as follows.

External tension is measured as the level of specific conflicts and difficulties experienced by top managers who work with contradictory logics of coopetition simultaneously. Based on previous research on coopetitive tension, we define external tension as the tension experienced from pursuing conflicting goals and economic interest (Fang et al., 2011), the difficulty in balancing these interests (Bengtsson et al., 2010), the difficulties in simultaneously performing activities based on contradicting logics of interaction (Bengtsson \& Kock, 2000), and the difficulties in simultaneously co-creating and appropriating value (Gnyawali et al., 2012, Ritala \& Sainio, 2014).

Internal tension is measured as the level of conflict within the organization, perceived by top managers. Internal tension is defined as conflicting values and frustration within the organization that developed as a result of coopetitive relationship (Raza-Ullah et al., 2014).

Coopetition capability is measured as the ability to accommodate two contradicting logics and interactions simultaneously, and is based on insights from three literature streams - coopetition, paradox, and ambidexterity. The measure includes the following four items: The cognitive complexity that enables managers to understand when and why it is 
beneficial to engage in cooperation and competition (Denison et al., 1995); the ability to develop alternative strategies or behavior repertoires in order to respond appropriately to contradicting demands (Denison et al., 1995; Eisenhart et al., 2010); the ability to change the scope and content of the relationship (Mom et. al., 2009); and the ability to balance contradicting demands related to cooperation and competition (Gibson \& Birkinshaw, 2004).

Covariates. We measure absorptive capacity by using Lane, Koka \& Patha'sk (2006) conceptualization that identifies exploratory learning, transformative learning and exploitative learning aspects. Networking capability is a three-item measure adapted from Walter et al (2006). We measure firm size as number of employees reported in the Statistics Sweden registry, and use dummy coding to capture the effects of the industry affiliation and firm location.

\subsection{Measurement properties of multi-item constructs}

We assessed the reliability, convergent and discriminant validities of multiple-item constructs by specifying a full confirmatory factor analysis (CFA) model reported in Table 3. Overall, the fit of the five-factor CFA measurement model is very good: Standardized root mean squared residual $\mathrm{SRMR}=.046$; Root mean squared error of approximation RMSEA=0.056; comparative fit index CFI $=0.964$; and Tucker-Lewis index TLI $=0.954$.

All standardized factor loadings are greater than .5 and significant at $\mathrm{p}<.00$. Further, all constructs show good internal consistency (ranging from .79 to .89 as measured by Cronbach's alpha). To assess discriminant validity of the proposed constructs we introduced pairwise restrictions of the correlation between the latent factors to 1 . The difference tests show significantly better model fits without these restrictions. Given the importance in differentiating between internal and external tensions we have also conducted additional assessments to ensure the distinctiveness of the constructs. Constraining the correlation between ET and IT in the full CFA model resulted in a significant loss of fit. Assessing the constructs separately also suggests that a two-factor solution (chi2 $(1)=7.26$, Prob $>$ chi $2=$ 0.0070; RMSEA $=0.073$ ) is by far superior to the one factor solution (chi2 $(2)=192.94$, Prob $>$ chi $2=0.0000 ;$ RMSEA $=0.287$ ).

\section{Table 3 about here}

Finally, we ruled out the possibility of common method bias (Podsakoff, MacKenzie, Lee $\&$ Podsakoff, 2003) by conducting a one-factor test. This test indicated that the one-factor model exhibits exceptionally poor fit: $\mathrm{SRMR}=.178$; RMSEA $=0.209$; comparative fit index $\mathrm{CFI}=0.392$; Tucker-Lewis index TLI $=0.305$.

Table 4 summarizes the key descriptive data of the variables in the model: means, and standard deviations and correlations.

Table 4 about here

\subsection{Model set-up}

We translated the relationships outlined in the conceptual model, presented in the Figure 1, into a set of two equations: 
(1) $E T=\alpha_{0}+\alpha_{1} \times P D X+\alpha_{2} \times C C+\alpha_{3} \times P D X \times C C+\sum_{k=1}^{15} \alpha_{3+k} \times C_{k}+\varepsilon_{E T}$.

(2) $I T=\beta_{0}+\beta_{1} \times E T+\beta_{2} \times P D X+\beta_{3} \times C C+\beta_{4} \times$ Size $+\varepsilon_{I T}$.

In the first equation, external tensions $E T$ are affected by coopetition paradox intensity $P D X$, coopetition capability $C C$, a multiplicative term $P D X \times C C$, and a set of $k=15$ covariates $C_{k}$ (12 industry dummies, 2 location dummies, and firm size). In the second equation, internal tensions $I T$ are affected by $P D X, E T, C C$ and firm size. As such, the first equation assesses hypotheses $\mathrm{H}_{1}$ and $\mathrm{H}_{3}$, and the second equation hypotheses $\mathrm{H}_{2}$ and $\mathrm{H}_{4}$. Please note that while not explicitly hypothesized in the model, we include a direct link $P D X \rightarrow I T$ at the specification stage in the interest of robustness.

We approached the model as a simultaneous equations system and estimate it using the three-stage least squares (3SLS) method (Greene, 2008), with both ET and IT being endogenous variables in the system. To keep the model identified, a full set of controls is not included in the second equation. To address the potential issue of multicollinearity, we meancentered the variables within interaction terms, $C C$ and PDX (Jaccard, 2003). The mean variance inflation factor (VIF) in the Eq. 1, excluding the categorical controls, is 1.16; VIFs for $P D X$ is $1.22, C C$ is 1.18 , and $P D X \times C C$ is 1.09 . Overall, multicollinearity is not a concern in the specified model.

\section{Results}

Table 5 reports the joint estimation results of the two equations. Both equations are highly significant overall at $\mathrm{p}<.00$. Examination of the results of the first equation (Eq. 1) shows that the intensity of coopetition paradox, $P D X$, has a positive and significant effect on external tensions ET $\left(\alpha_{1}=.073634, p<.00\right)$, thus confirming $\mathrm{H}_{1}$.

$\mathrm{H}_{3}$ suggests that coopetition capability $C C$ moderates the effect of $P D X$ on $E T$, and we examine the direction and significances of the coefficients $\alpha_{2}$ and $\alpha_{3}$ to assess this hypothesis. $C C$ has a significant and positive direct effect of $E T\left(\alpha_{2}=.2692788, p<.00\right)$, while the effect of the multiplicative term $P D X \times C C$ is negative and also significant $\left(\alpha_{3}=-.0253976, p<.00\right)$. These coefficients suggest that, compared to firms with lower levels of coopetition capability, firms with higher levels of coopetition capability will report higher levels of external tension at low paradox intensity levels and lower external tensions at high levels of paradox intensity. Hence, $\mathrm{H}_{3}$ is also supported.

Table 5 about here

To further assess the moderating effect of $C C$, we use Figure 3 to visualize the significant moderation effects. In the figure, high $C C$ and low $C C$ correspond to one standard deviation above and below the mean, respectively. Firms with low $C C$ experience a linear increase in $E T$ as the intensity of $P D X$ increases; firms with high $C C$ are unaffected by PDX intensity level changes and maintain a constant level of $E T$.

Figure 3 about here 
We additionally performed a median split of the $\mathrm{CC}$ variable (low $C C$ defined as bottom $50 \%$ of observations and high $C C$ as top $50 \%$ of observations) and estimated the average marginal effect $(\partial y / \partial x)$ of $P D X$ on $E T$ for firms in each group. The results are nearly identical to the one presented in Figure 2). Firms with high CC are unaffected by PDX intensity level changes and maintain a constant level of ET as the slope is not significantly different from $0(\partial y / \partial x=.0553274 ; \mathrm{p}=.212)$. Firms with Low CC $(\partial y / \partial x=.2455607$, $\mathrm{p}<.00$ ), on the other hand, experience $E T$ increase as $P D X$ increases.

The effects of coopetition capability and external tensions on internal tensions $I T$, specified in $\mathrm{H}_{2}$ and $\mathrm{H}_{4}$, are reported under equation 2 in Table 5. In line with the expectations, variable ET is positively related to $I T\left(\beta_{1}=.5045424, p<.00\right)$, yielding support to $\mathrm{H}_{2}$. Coopetition capability $C C$, on the other hand, negatively affects IT, suggesting that firms with higher levels of $C C$ generally experience less internal tension, thus providing support to $\mathrm{H}_{4}$. The effect, however, is significant at only $\mathrm{p}<.1\left(\beta_{3}=-.0456612, p=.063\right)$.

The control variables included in the model also show a range of significant effects. Firm size is positive and significant in both equations, suggesting that larger firms experience higher levels of both external and internal tensions. Firms in 'Information and Communication' industry reported higher levels of external tensions compared to other industries. Finally, networking capability has a negative effect on external tension formation, while higher levels of absorptive capacity, other things being equal, are associated with higher levels of external tensions.

Naturally, we conducted a range of the robustness and stability checks to establish whether the reported results are sensitive to specification and estimation choices. We have estimated models with various control combinations with necessary adjustments to keep the model identified; the substantive results are not affected. We also used alternative specifications of both dependent variables and controls: estimating the model without meancentering the interacting variables, using log-transformed values of size, removing items with smaller loadings from constructs, and removing potential outliers per Mahalanobis distance. Overall, the results are stable, as the direction and significance of the reported effects do not change. To sum up, the results provide support hypotheses $\mathrm{H}_{1}$ to $\mathrm{H}_{4}$.

\section{Discussion and conclusion}

The central goal of this research was to examine how the paradoxical nature of coopetition can create tension and to suggest how coopetition capability can enable managers to deal with such tension. Our findings show that external tension forms as a result of the paradoxical state of coopetition and that such external tension formation is conditional upon the level of coopetition capability possessed by the firm. Coopetition capability also helps to reduce internal tensions by contributing to the development of a shared understanding of the coopetition benefits and by reducing the frustration experienced within the organization.

\section{Contributions and Implications for the Coopetition Literature}

Our study contributes to research on coopetition in several ways. First, we show that studying coopetition as a paradox provides a more nuanced understanding of how coopetitive tensions develop as a result of coopetition engagement between firms. Our study provides evidence that the degree of coopetitive tension experienced by managers (i.e., external tension) depends on the intensity of cooperative and competitive interactions between firms (i.e., strength of coopetition paradox). The results imply that a strong paradox would trigger high tension while a weak paradox would give rise to low tension. Tension also develops at the lower levels of the firm (internal tension). Prior studies have mainly studied internal tension that develops as a result of intra-firm coopetition (Tsai, 2002; Luo, 2005; Luo et al., 
2006). Our study advances knowledge on internal tension by examining its presence in an inter-firm coopetitive setting (through top managers' perception of it). The results suggest that top managers' experience of external tension increases their awareness of internal tension that exists at lower levels of the firm. Thus, our study enhances the current understanding on the paradoxical and tension-filled nature of coopetition (Fernandez et al., 2014; Raza-Ullah et al., 2014) by empirically establishing that coopetition is indeed a paradox that generates tensions.

Second, we enrich the conception of coopetition capability-the ability to think paradoxically and to initiate processes that help firms attain and maintain a moderate level of tension, irrespective of the paradox intensity level. Our results show that coopetition capability moderates the impact of coopetition paradox on external tension. Previous research suggests that a moderate level of tension, in contrast to low or high levels, is necessary and beneficial for firms' coopetitive performance (Gnyawali et al., 2012; Raza-Ullah \& Bengtsson, 2014). We contribute by suggesting that coopetition capability serves both as a necessary and a fundamental condition to attain and maintain the tension on a moderate level. We refer the reader back to Figure 3, which illustrates that firms with higher levels of coopetition capability maintain a moderate level of external tension, almost irrespective of the strength of coopetition paradox (as the slope coefficient is positive but not significant by conventional levels). The flip side of the result shows that firms with underdeveloped coopetition capability would either disregard the tension when the paradox strength is low, or become paralyzed by experiencing exceedingly high tension when the paradox becomes stronger (Raza-Ullah \& Bengtsson, 2014; Stratton, 2005). Either of these situations is detrimental and not desirable from the point of benefiting from the relationship (c.f. Park et al., 2014).

Third, we contribute by showing that coopetition capability plays an additional role such that it enables firm to reduce internal tension. Our results support the argument that coopetition capability allows a firm to avert external tensions from spilling over into the organization. This is fruitful because lower level employees are typically considered less competent than top managers to understand and tackle contradictions. Top managers or executives must be able to perceive the internal tensions because ultimately they are the ones who would accommodate the two contradicting agendas between separate departments, allocate reasonable resources to each agenda (Brown \& Eisenhardt 1997; Eisenhardt, et al., 2010), and communicate the advantages of coopetition internally.

Finally, we provide a novel perspective on the suitability of specific coopetition capability in coopetition-specific relationships in contrast to general alliance capabilities such as networking capability (e.g. Walter et al., 2006) and absorptive capability (Cohen \& Levinthal, 1990). Our results prove that general capabilities do not fully account for the coopetitive tensions in coopetition-specific relationships, unless firms possess coopetition capability.

\section{Contributions and Implications for the Paradox Literature}

First, our research contributes to the paradox literature by highlighting the distinction between the constructs of paradox and tension. In paradox literature, very often both constructs are used interchangeable and treated alike (Jarvenpaa \& Wernick, 2011; Vince \& Broussine, 1996). Our findings suggest that although directly and positively related to each other, both constructs are distinct such that a paradox is an antecedent of tension (Raza-Ullah et al., 2014). Our study suggests that the paradox of coopetition develops through the cooperative and competitive interactions of firms, while tension is the experienced difficulty of working with contradictory tasks simultaneously. Second, much of paradox literature addresses organizational paradoxes and tensions such as exploration-exploitation (Smith \& Tushman, 2005), flexibility-efficiency (Adler, Goldoftas, \& Levine, 1999), and stability- 
change (Lean \& Barry, 2000). Little is known about inter-firm paradoxes that are more dynamic and challenging from organizational paradoxes for two key reasons. One, they do not involve a common hierarchy or a governance structure, and two; they develop between organizations that have different identities, cultures, and conflicting interests. Our study provides useful insights on which paradox research can build and further explore paradoxes at an inter-firm level.

\section{Implications for Management}

Our finding that coopetition capability has a moderating role on the impact of coopetition intensity and resultant tension implies that coopetition capability is a must-have skill for all firms involved in coopetition to succeed. Huge failure rates of coopetitive alliances (Lunnan \& Haugland, 2008) suggest that despite having general alliance capabilities, firms would still need specific coopetition capability particularly when it cooperates and competes simultaneously with another firm. Our results indicate that intense coopetition for instance would result into experience of high tension. Further, our results seem to suggest that lack of coopetition capability would suggest that managers would tend to reduce high tension by tipping toward either cooperation or competition. This would in turn exacerbate the imbalance and the relationship would likely dissolve into either a merger/acquisition or a purely competitive one (Das \& Teng, 2000). Higher level of coopetition capability in such a situation would help managers maintain a moderate tension, which would likely improve the balance between cooperation and competition.

Our study also has implications concerning managers' perception and awareness of internal tension. Internal tension would likely sabotage the overall results of coopetition if top managers do not reduce the resultant frustrations and disagreements of lower level employees about a coopetitive relationship. Thus they need to clearly communicate the rationale of a coopetitive relationship that seems odd to departments either cooperating or competing with the coopetitive firm.

\section{Limitations and further directions}

Our study reflects several limitations, which in turn opens up future research opportunities. First, it uses a multiplicative measure of coopetition paradox-an approach that captures only the intensity aspects of cooperation and competition. Although this approach looks appropriate to determine how extreme (intense) cooperative and competitive interactions are, yet it does not capture how alike (similar) are cooperation and competition in opposition to each other. Future research should incorporate both the intensity and the similarity aspects when measuring coopetition paradox. Further, we measured competition and cooperation intensities with single items. Using multi-item scales, similar to those developed by Chen, Xie \& Chang (2011), would provide finer nuances of paradox conceptualization. Second, we mainly focused on studying the mechanics of tension formation and the role of coopetition capability in this study. Future research should also include performance variables to examine how tension impacts performance and what would the role of coopetition capability be in enhancing a firm's performance. Third, our study relies on responses by the CEOs exclusively and we did not examine the tension experienced by individuals in different units and levels with conflicting values and identities (Das \& Teng, 2000; Näsholm \& Bengtsson, 2013; Van de Ven, 1992). Thus, our study exclusively speaks to the executives and top managers of the firm and relies on their perception of internal tensions. Additionally, while our study makes an important contribution in examining the phenomenon of internal tensions, multiple-respondent and qualitative studies are needed to carry this line of work further. Future studies should analyze the perception of tensions within the organization and compare managers' perceptions of internal tension with internal tension experienced by individuals in different units and on different levels. 


\section{References}

Adler, P. S., Goldoftas, B., \& Levine, E. (1999) Flexibility vs. efficiency? A case study of model changeovers in the Toyota Product System. Organization Science, 10: 43-68.

Ambos, T.C., Mäkelä, K., Birkinshaw, J., \& D’Este, P. (2008). When Does University Research Get Commercialized? Creating Ambidexterity in Research Institutions. Journal of Management Studies, 45(8), 1424-1447.

Andriopoulos, C., \& Lewis, M.W. (2008). Managing Innovation Paradoxes: Ambidexterity Lessons from Leading Product Design Companies. Long Range Planning, 43, 104-122.

Bengtsson, M., \& Johansson, M. (2014). Managing coopetition to create opportunities for small firms, International Small Business Journal, 32(4), 401-427

Bengtsson, M., \& Kock, S. (2000). "Coopetition" in business networks - To cooperate and compete simultaneously. Industrial Marketing Management, 29(5), 411-426.

Bengtsson, M., Eriksson, J., \& Wincent, J. (2010). Co-opetition dynamics-An outline for further inquiry. Competitiveness Review: An International Business Journal incorporating Journal of Global Competitiveness, 20(2), 194-214.

Brandenburger, A.M., \& Nalebuff, B.J. (1996). Co-opetition. New York: Bantam Doubleday Dell Publishing Group.

Brown, S.L., \& Eisenhardt, K.M., (1997). The art of continuous change: Linking complexity theory and time-paced evolution in relentlessly shifting organizations. Administrative Science Quarterly, 42(1), 1-34.

Camison-Zornoza, C., Lapiedra-Alcami, R., Segarra-Cipres, M. \& Boronat-Navarro, M. (2004). A Meta-Analysis of Innovation and Organizational Size. Organization Studies, 25(3), 331-61.

Cameli, A., \& Halevi, M.Y. (2009). How top management team behavioral integration and behavioral complexity enable organizational ambidexterity: The moderating role of contextual ambidexterity. The Leadership Quarterly. 20, 207-218.

Chen, X-P., Xie, X., \& Chang, S. (2011). Cooperative and competitive orientations among Chinese People: Scale Development and Validation. Management and Organization Review, 7(2), 353-379.

Cohen, W.M., \& Levinthal, D.A. (1990). Absorptive capacity: A new perspective on learning and innovation. Administrative Science Quarterly, 35 (1), 128-152.

Dagnino, G.B., \& Padula, G. (2002). Coopetition strategy: a new kind of interfirm dynamics for value creation. EURAM second annual conference, Stockholm, Sweden, May 9-11, 2002 .

Das, T.K., \& Teng, B.S. (1999). Cognitive biases and strategic decision processes: An integrative perspective. Journal of Management Studies, 36(6), 757-778.

Das, T.K., \& Teng, B.S. (2000). Instabilities of strategic alliances: an internal tensions perspective. Organization Science, 11(1), 77-101.

Deming, W.E. (1993). The new economics. Cambridge: Massachusetts Institute of Technology, Center for Advanced Engineering Study.

Denison, D.R., Hooijberg, R., \& Quinn, R.E. (1995). Paradox and performance: Toward a theory of behavioral complexity in managerial leadership. Organization Science, 6(5), 524-540.

Dess, G.G., Ireland, R.D., \& Hitt, M.A. (1990). Industry effects and strategic management research. Journal of Management, 16(1), 7-27.

DeVellis, R.F. (1991). Scale Development: theory and applications (Applied Social Research Methods Series, Vol. 26). Newbury Park: Sage. 
Dowling, M.J., Roering, W.D., Carlin, B.A., \& Wisnieski, J. (1996). Multifaceted relationships under coopetition description and theory. Journal of Management Inquiry, 5(2), 155-167.

Duncan, R.B. (1976). The Ambidextrous organization: Designing Dual Structures for Innovation. In R. Kilman, \& L., Pondy (eds.). The Management of Organizational Design (pp.167-188). New York: North Holland.

Eisenhardt, K.M. (2000). Paradox, spirals, ambivalence: the new language of change and pluralism. Academy of Management Review, 25(4), 703-705.

Eisenhardt, K.M., Furr, N.R., \& Bingham, C.B. (2010). CROSSROADS-Microfoundations of Performance: Balancing Efficiency and Flexibility in Dynamic Environments. Organization Science, 21(6), 1263-1273.

Fang, S.R., Chang, Y.S., \& Peng, Y.C. (2011). Dark side of relationships: A tensions-based view. Industrial Marketing Management, 40(5), 774-784.

Fernandez, A.S., Le Roy, F., \& Gnyawali, D.R. (2014). Sources and management of tension in co-opetition case evidence from telecommunications satellites manufacturing in Europe. Industrial Marketing Management, 43(2), 222-235.

Floyd, S.W., \& Lane, P.J. (2000). Strategizing throughout the organization: Managing role conflict in strategic renewal. Academy of Management Review, 25(1), 154-177.

Garud, R., \& Kumaraswamy, A. (1995). Technological and organizational designs for realizing economies of substitution. Strategic Management Journal, 16(S1): 93-109.

Gertler, M.S., Wolfe, D.A., \& Garkut, D. (2000). No place like home? The embeddedness of innovation in a regional economy. Review of International Political Economy, 7(4), 688718.

Gibson, C.B., \& Birkinshaw, J. (2004). The Antecedents, Consequences, and Mediating Role of Organizational Ambidexterity. Academy of Management Journal, 47(2), 209-226.

Gnyawali, D.R., \& Park, B.J.R. (2011). Co-opetition between giants: Collaboration with competitors for technological innovation. Research Policy, 40(5), 650-663.

Gnyawali, D.R., Madhavan, R.M., He, J. and Bengtsson, M. (2012). 'Contradictions, Dualities and Tensions in Cooperation and Competition: A Capability Based Framework' Presented at the Annual Meeting of the Academy of Management, Boston, $M A$.

Greene, W.H. (2008). Econometric Analysis. 6th ed. Upper Saddle River, NJ: Prentice-Hall.

Harbison, J.R., \& Pekar Jr. P. (1998). Smart Alliances. Jossey-Bass, San Francisco.

He, Z.L., \& Wong, P.K. (2004). Exploration vs. exploitation: An empirical test of the ambidexterity hypothesis. Organization science, 15(4), 481-494.

Helfat, C.E., \& Winter, S.G. (2011). Untangling dynamic and operational capabilities: Strategy for the (N).ever-changing world. Strategic Management Journal, 32(11), 12431250 .

Im, G., \& Rai, A. (2008). Knowledge sharing ambidexterity in long-term interorganizational relationships. Management Science, 54(7), 1281-1296.

Jarvenpaa, S. L., \& Wernick, A. (2011). Paradoxical tensions in open innovation networks. European Journal of Innovation Management, 14(4), 521-548.

Jaccard J. (2003). Interaction Effects in Multiple Regression. Sage: Thousand Oaks, CA

Khanna, T., Gulati, R., \& Nohria, N. (1998). The dynamics of learning alliances: Competition, cooperation, and relative scope. Strategic Management Journal, 19(3), 193-210.

Lado, A.A., Boyd, N.G., \& Hanlon, S.C. (1997). Competition, cooperation, and the search for economic rents: A syncretic model. Academy of Management Review, 22(1), 110-141. 
Lane, P.J., Koka, B.R., \& Pathak, S. (2006). The reification of absorptive capacity: A critical review and rejuvenation of the construct. Academy of Management Review, 31 (4), 833863.

Leana, C. R., \& Barry, B. (2000). Stability and change as simultaneous experiences in organizational life. Academy of Management Review, 25(4), 753-759.

Lewis M.W. (2000). Exploring Paradox: Toward a more comprehensive guide. Academy of Management Review, 25(4), 760-776.

Lewicki, R.J., McAllister, D.J., \& Bies, R.J. (1998). Trust and distrust: New relationships and realities. Academy of Management Review, 23(3), 438-458.

Li, D., Eden, L., Hitt, M.A., Ireland, R.D., \& Garrette, R.P. (2012). Governance in multilateral R\&D alliances. Organization Science, 23(4), 1191-1210.

Lin, Z., Yang, H., \& Demirkan, I (2007). The Performance Consequences of Ambidexterity in Strategic Alliance Formations: Empirical Investigation and Computational Theorizing. Management Science, 53(10), 1645-1658.

Lubatkin, M.H., Simsek, Z., Ling, Y., \& Veiga, J.F. (2006). Ambidexterity and performance in small-to medium-sized firms: The pivotal role of top management team behavioral integration. Journal of management, 32(5), 646-672.

Lunnan, R., \& Haugland, S. (2008). Predicting and measuring alliance performance: A multidimensional analysis. Strategic Management Journal, 29(5), 545-556.

Luo, Y. D. (2005). Toward coopetition within a multinational enterprise: a perspective from foreign subsidiaries. Journal of World Business, 40(1), 71-90.

Luo, Y. (2007). A coopetition perspective of global competition. Journal of World Business, $42(2), 129-144$.

Luo, X., Slotegraaf, R.J., \& Pan, X. (2006). Cross-functional co-opetition: The simultaneous role of cooperation and competition within firms. Journal of Marketing, 70, 67-80.

Mariani, M. M. (2007). Coopetition as an emergent strategy: Empirical evidence from an Italian consortium of opera houses. International Studies of Management \& Organization, 37(2), 97-126.

Mom, T.J., Van Den Bosch, F.A., \& Volberda, H.W. (2009). Understanding variation in managers' ambidexterity: Investigating direct and interaction effects of formal structural and personal coordination mechanisms. Organization Science, 20(4), 812-828.

Näsholm H. M. \& Bengtsson M., (2014) A conceptual model of individual identifications in the context of coopetition International Journal of Business Environment, 6(1), 11-27.

Oliver, A. L. (2004). On the duality of competition and collaboration: network-based knowledge relations in the biotechnology industry. Scandinavian Journal of Management, 20(1/2), 151-171.

Padula, G., \& Dagnino, G.B. (2007). Untangling the Rise of Coopetition. International Studies of Management \& Organization, 37(2), 32-52.

Park, B.J.R., Srivastava, M.K., \& Gnyawali, D.R. (2014). Walking the tight rope of coopetition: Impact of competition and cooperation intensities and balance on firm innovation performance. Industrial Marketing Management, 43(2), 893-907.

Park, S.H. and Ungson G.R. (2001). Interfirm rivalry and managerial complexity: A conceptual framework of alliance failure, Organization Science, 12, 37-53.

Pouder, R. \& St John, C. (1996), "Hot Spots and Blind Spots: Geographical Clusters of Firms and Innovation", Academy of Management Review, 21(4), 1192-1225.

Podsakoff P.M., MacKenzie, S.B., Lee, J.Y, \& Podsakoff, N.P. (2003). Common method biases in behavior research: A critical review of the literature and recommended remedies" Journal of Applied Psychology, 88(5), 879-903.

Poole, M.S., \& Van de Ven, A.H. (1989). Using paradox to build management and organization theories. Academy of Management Review, 14(4), 562 - 578. 
Raza-Ullah, T., \& Bengtsson, M. (2013). Tension in Paradoxical Relationships between Firms. Paper presented at 29th EGOS collopuim, Montréal, Canada, July 4-6, 2013.

Raza-Ullah, T., \& Bengtsson, M. (2014). Emotions in paradoxical inter-firm relationships: A conceptual framework. Paper presented at the 74th Annual Meeting of the Academy of Management - August 1-5, 2014 - Philadelphia, PA.

Raza-Ullah, T., Bengtsson, M., \& Kock, S. (2014). The coopetition paradox and tension in coopetition at multiple levels. Industrial Marketing Management 43(2), 189-198.

Ritala, P., \& Hurmelinna-Laukkanen, P. (2013). Incremental and radical innovation in coopetition - the role of absorptive capacity and appropriability. Journal of Product Innovation Management, 30(1), 154-169.

Ritala, P., \& Sainio, L. (2014). Coopetition for Radical Innovation: Technology, Market and Business-Model Perspectives. Technology Analysis And Strategic Management, 26(2), 155-169.

Smith, W.K., \& Lewis, M.W. (2011). Toward a theory of paradox: A dynamic equilibrium model of organizing. Academy of Management Review, 36(2), 381-403.

Smith, W.K., \& Tushman, M.L. (2005). Managing strategic contradictions: A top management model for managing innovation streams. Organization science, 16(5), 522536.

Stratton (2005). An affective events theory-based conceptual model of emotional ambivalence in the context of personal web-usage monitoring. Research on Emotion in Organizations, $1,47-76$.

Tidström, A. 2014. Managing tensions in co-opetition. Industrial Marketing Management, 43(2): 261-271.

Tsai, W. (2002). Social structure of "coopetition" within a multiunit organization: Coordination, competition, and intraorganizational knowledge sharing. Organization Science, 13(2), 179-190.

Uzzi, B. (1997). Social structure and competition in interfirm networks: The paradox of embeddedness. Administrative science quarterly, 42(1), 35-67.

Vince, R., \& Broussine, M. (1996) Paradox, defense and attachment: Accessing and working with emotions and relations underlying organizational change. Organization Studies, 17: $1-21$.

Walter A., Auer M., \& Ritter T. (2006). The impact of networking capabilities and entrepreneurialorientation on university spin-off performance, Journal of Business Venturing, 21(4.), 541-567.

Wang, Y., \& Rajagopalan, N. (2015). Alliance Capabilities Review and Research Agenda. Journal of Management, 41(1), 236-260.

Wu, Z., Choi, T.Y., \& Rungtusanatham, M.J. (2010). Supplier-supplier relationships in buyer-supplier-supplier triads: Implications for supplier performance. Journal of Operations Management, 28(2), 115-123.

Yami, S., Castaldo, S., Dagnino, B., \& Le Roy, F. (Eds.). (2010). Coopetition: winning strategies for the 21st century. Edward Elgar Publishing. 
Table 1: Population and sampling approach

\begin{tabular}{lcccc}
\hline Stratum & $\begin{array}{c}\text { Number of firms } \\
\text { in population, N }\end{array}$ & $\begin{array}{c}\text { Sampled } \\
\text { firms, N }\end{array}$ & $\begin{array}{c}\text { Responding } \\
\text { firms, N }\end{array}$ & $\begin{array}{c}\text { Response } \\
\text { rate, \% }\end{array}$ \\
\hline $\begin{array}{l}\text { Northern Sweden, } \\
\quad 10-249 \text { employees }\end{array}$ & 4627 & 2448 & 771 & 31.50 \\
$\begin{array}{c}\text { Northern Sweden, } \\
250-499 \text { employees }\end{array}$ & 52 & 52 & 17 & 32.69 \\
$\begin{array}{c}\text { South and East Sweden, } \\
\quad 10-249 \text { employees }\end{array}$ & 22956 & 2112 & 620 & 29.36 \\
$\begin{array}{c}\text { South and East Sweden, } \\
\quad 250-499 \text { employees }\end{array}$ & 388 & 388 & 124 & 31.96 \\
Total & $\mathbf{2 8 0 2 3}$ & $\mathbf{5 0 0 0}$ & $\mathbf{1 5 3 2}$ & $\mathbf{3 0 , 6 4}$ \\
\hline
\end{tabular}

Table 2: Sample description and response rates: industry and localization

\begin{tabular}{|c|c|c|c|c|c|}
\hline \multirow[b]{2}{*}{$\begin{array}{l}\text { Swedish Standard Industrial } \\
\text { Classification } 2007\end{array}$} & \multicolumn{2}{|c|}{ Sample } & \multicolumn{2}{|c|}{ Respondents } & \multirow[b]{2}{*}{$\begin{array}{c}\text { Response } \\
\text { rate, \% }\end{array}$} \\
\hline & $\begin{array}{l}\text { Number of } \\
\text { firms in } \\
\text { the sample, } \\
\mathrm{N}\end{array}$ & $\begin{array}{c}\text { Share of } \\
\text { firms in } \\
\text { the sample, } \\
\%\end{array}$ & $\begin{array}{l}\text { Number of } \\
\text { responding } \\
\text { firms, N }\end{array}$ & $\begin{array}{l}\text { Share of } \\
\text { responding } \\
\text { firms, } \%\end{array}$ & \\
\hline $\begin{array}{l}\text { (A) Agriculture, Forestry and } \\
\text { Fishing }\end{array}$ & 120 & 2.4 & 35 & 2.3 & 29.2 \\
\hline (B) Mining and Quarrying & 24 & .5 & 11 & .7 & 45.8 \\
\hline (C) Manufacturing & 1295 & 25.9 & 482 & 31.5 & 37.2 \\
\hline $\begin{array}{l}\text { (D) Electricity, Gas, Steam and } \\
\text { Air Conditioning Supply } \\
\text { (E) Water Supply; Sewerage, }\end{array}$ & 56 & 1.1 & 20 & 1.3 & 35.7 \\
\hline $\begin{array}{l}\text { Waste Management and } \\
\text { Remediation Activities }\end{array}$ & 42 & .8 & 19 & 1.2 & 45.2 \\
\hline (F) Construction & 939 & 18.8 & 240 & 15.7 & 25.6 \\
\hline (H) Transportation and Storage & 505 & 10.1 & 133 & 8.7 & 26.3 \\
\hline $\begin{array}{l}\text { (I) Accommodation and } \\
\text { Foodservice Activities }\end{array}$ & 466 & 9.3 & 89 & 5.8 & 19.1 \\
\hline $\begin{array}{l}\text { (J) Information and } \\
\text { Communication }\end{array}$ & 286 & 5.7 & 89 & 5.8 & 31.1 \\
\hline $\begin{array}{l}\text { (M) Professional, Scientific and } \\
\text { Technical Activities }\end{array}$ & 446 & 8.9 & 151 & 9.9 & 33.9 \\
\hline $\begin{array}{l}\text { (N) Administrative and Support } \\
\text { Service Activities }\end{array}$ & 387 & 7.7 & 103 & 6.7 & 26.6 \\
\hline $\begin{array}{l}\text { (Q) Human Health and Social } \\
\text { Work Activitie }\end{array}$ & 273 & 5.5 & 102 & 6.7 & 37.4 \\
\hline (L) Real Estate Activities & 161 & 3.2 & 58 & 3.8 & 36.0 \\
\hline \multicolumn{6}{|l|}{$\begin{array}{l}\text { Localization according to } \\
\text { NUTS3 }\end{array}$} \\
\hline East Sweden & 1281 & 25,62 & 366 & 23,89 & 28.57 \\
\hline South Sweden & 1219 & 24,38 & 378 & 24,67 & 31.01 \\
\hline North Sweden & 2500 & 50,00 & 788 & 51,44 & 31.52 \\
\hline Total & 5000 & 100 & 1532 & 100 & 30.6 \\
\hline
\end{tabular}


Table 3: Measurement model

\begin{tabular}{lllll}
\hline Constructs & Measurement Items & $\begin{array}{c}\text { Factor } \\
\text { loading }\end{array}$ & $z$ & alpha \\
\hline
\end{tabular}

External Tensions (ET): To what extent (1-not at all / 5-very high extent)

do conflicts arise as a consequence of both cooperating and competing with your partner?

is it difficult to cooperate in one area and compete in another?

is it difficult to create value together and simultaneously appropriate private benefits?

$.84 \quad 66.43$

is it difficult to balance conflicting economic interests?

Internal Tensions (IT:) To what extent (1-not at all / 5-very high extent) do the units within the organization have different opinions about the value provided by the cooperation with your competitor? does the relationship lead to demands and expectations that create frustration within the organization?

Coopetition Capability (CC:) In your coopetition relationships with other firms how important is it to (1-not at all / 5-very high extent)

understand when and why it is a benefit to cooperate and compete?

develop alternative strategies to manage both cooperation and competition?

to continuously change the scope content of the relationship?

to balance contradicting demands without jeopardizing the relationship?

Networking Capability (NC): To what extent (1-not at all / 5-very high extent) do you build personal relationships with your partners? $\quad .78 \quad$ Fixed $\begin{array}{lll}\text { do you and your partner constructively solve problems } & .77 & 42.34\end{array}$ together when they arise?

42.34
are you aware of the strength and weakness of your partner?

Absorptive Capacity (AC): To what extent does your firm (1-not at all / 5-very high extent) follow technological trends?

$.70 \quad 21.36$
have the capacity to see how new knowledge or technology can be used?

$\begin{array}{ll}.92 & 43.95\end{array}$
have the capacity to connect new business opportunity with the knowledge or competences that exist in you firm?

$.67 \quad 19.90$

Table 4. Means, standard deviations, and a correlation matrix

\begin{tabular}{ccccccccccc}
\hline & & Mean & $\mathrm{s}, \mathrm{d}$, & 1 & 2 & 3 & 4 & 5 & 6 & 7 \\
\hline 1 & $E T$ & 10.82 & 3.04 & 1 & & & & & & \\
2 & $I T$ & 4.45 & 1.76 & 0.65 & 1 & & & & & \\
3 & $P D X$ & 7.51 & 3.86 & 0.13 & 0.10 & 1 & & & & \\
4 & $C C$ & 13.77 & 3.36 & 0.30 & 0.19 & 0.24 & 1 & & & \\
5 & $N C$ & 11.14 & 2.17 & 0.05 & 0.00 & 0.29 & 0.29 & 1 & & \\
6 & AC & 13.19 & 2.80 & 0.13 & 0.10 & 0.21 & 0.24 & 0.32 & 1 & \\
7 & Size & 57.74 & 96.72 & 0.12 & 0.17 & 0.08 & 0.12 & 0.02 & 0.09 & 1 \\
\hline
\end{tabular}




\begin{tabular}{|c|c|c|c|c|}
\hline & parameter & s.e. & $\mathbf{z}$ & $\mathbf{p}$ \\
\hline Eq. 1 : External Tensions $(E T)$ & $\alpha$ & & & \\
\hline$P D X$ & .073634 & .0253702 & 2.90 & 0.004 \\
\hline$C C$ & .2692788 & .0286198 & 9.41 & 0.000 \\
\hline$P D X \times C C$ & -.0253976 & .0065768 & -3.86 & 0.000 \\
\hline $\mathrm{NC}$ & -.1073117 & .0440737 & -2.43 & 0.015 \\
\hline $\mathrm{AC}$ & .082065 & .0332321 & 2.47 & 0.014 \\
\hline Size & .0022801 & .000964 & 2.37 & 0.018 \\
\hline \multicolumn{5}{|l|}{ Location } \\
\hline South Sweden & .1720985 & .2507758 & 0.69 & 0.493 \\
\hline North Sweden & .0134638 & .2222903 & 0.06 & 0.952 \\
\hline \multicolumn{5}{|l|}{ Industry } \\
\hline (A) Agriculture, Forestry and Fishing & -.4600937 & 1.245333 & -0.37 & 0.712 \\
\hline (B) Mining and Quarrying & .4989684 & .568909 & 0.88 & 0.380 \\
\hline (C) Manufacturing & -.3285509 & 1.335226 & -0.25 & 0.806 \\
\hline $\begin{array}{l}\text { (D) Electricity, Gas, Steam and Air Conditioning } \\
\text { Supply }\end{array}$ & .4333744 & .9600398 & 0.45 & 0.652 \\
\hline $\begin{array}{l}\text { (E) Water Supply; Sewerage, Waste Management } \\
\text { and Remediation Activities }\end{array}$ & .7939391 & .5829465 & 1.36 & 0.173 \\
\hline (F) Construction & .1200713 & .6091245 & 0.20 & 0.844 \\
\hline (H) Transportation and Storage & .6156395 & .6120678 & 1.01 & 0.314 \\
\hline (I) Accommodation and Foodservice Activities & .6488366 & .6374022 & 1.02 & 0.309 \\
\hline (J) Information and Communication & 1.180773 & .6249845 & 1.89 & 0.059 \\
\hline $\begin{array}{l}\text { (M) Professional, Scientific and Technical } \\
\text { Activities }\end{array}$ & -.2469644 & 6304999 & -0.39 & 0.695 \\
\hline (N) Administrative and Support Service Activities & .6905746 & .6834478 & 1.01 & 0.312 \\
\hline (Q) Human Health and Social Work Activities & .8090865 & .7368811 & 1.10 & 0.272 \\
\hline Constant & 10.20857 & .8180366 & 12.48 & 0.000 \\
\hline $\mathrm{R}^{2}\left(\chi^{2} ; \mathrm{p}\right)$ & \multicolumn{4}{|c|}{$0.1348 \quad(161.96 ; 0.0000)$} \\
\hline Eq. 2: Internal Tensions (IT) & $\beta$ & & & \\
\hline$E T$ & .5045424 & .0800898 & 6.30 & 0.000 \\
\hline$P D X$ & .0039452 & .012087 & 0.33 & 0.744 \\
\hline$C C$ & -.0456612 & .0245852 & -1.86 & 0.063 \\
\hline Size & .0013969 & .0004966 & 2.81 & 0.005 \\
\hline Constant & -1.08992 & .8513792 & -1.28 & 0.200 \\
\hline $\mathrm{R}^{2}\left(\chi^{2} ; \mathrm{p}\right)$ & & (142.88; & $0.0000)$ & \\
\hline
\end{tabular}

Note: $\mathrm{R}^{2}$ values are only reported in the interest of completeness as they are difficult to interpret in three-stage least squares 


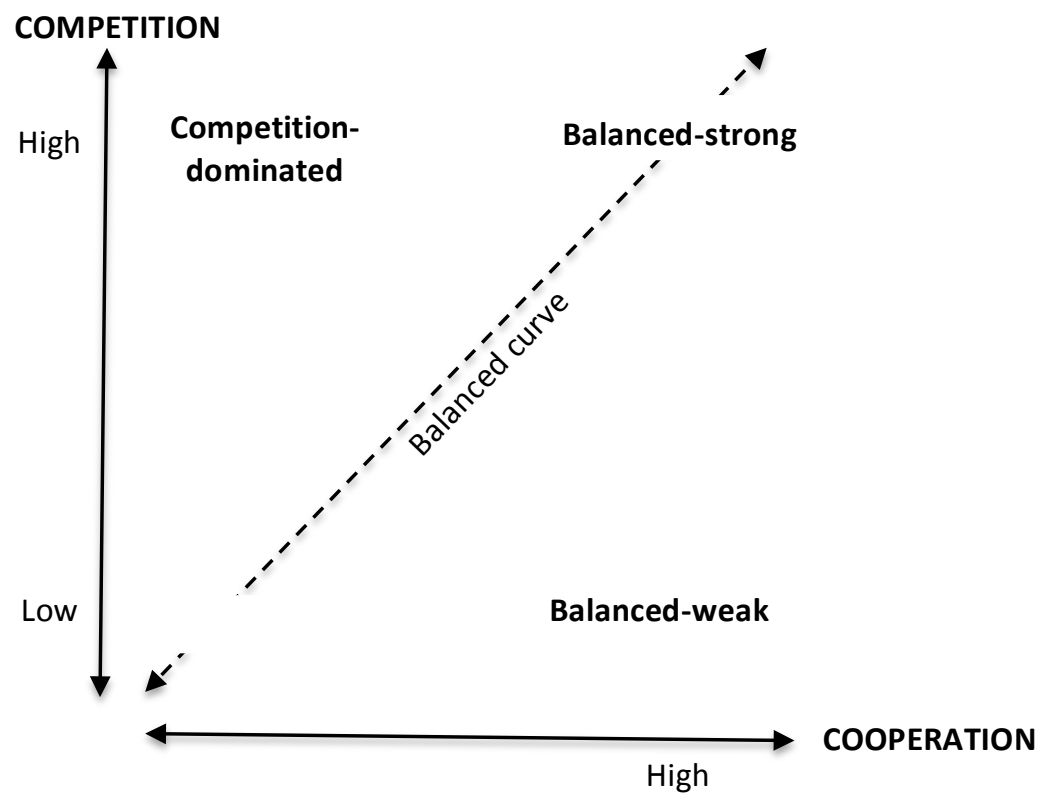


Coopetition capability

To understand when and why

to involve in $C \& C$

Develop alternative

strategies

Change scope and content

Balance contradictions

Coopetition paradox

Intensity in competition

Intensity in cooperation

\section{External tension}

Conflict between cooperation and competition activities Difficult to cooperate and compete simultaneously Value creation/appropriation Conflicting economic interest
H4

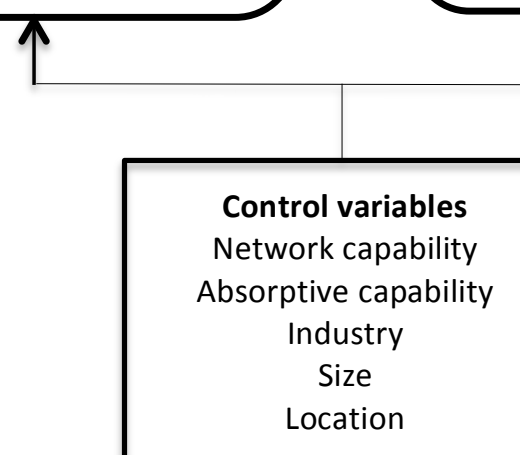

Internal tension

Different opinions

about the value of

coopetition

Frustrating demands and expectations

\section{Control variables}

Network capability Industry

Location

Fig 2. The theoretical model 


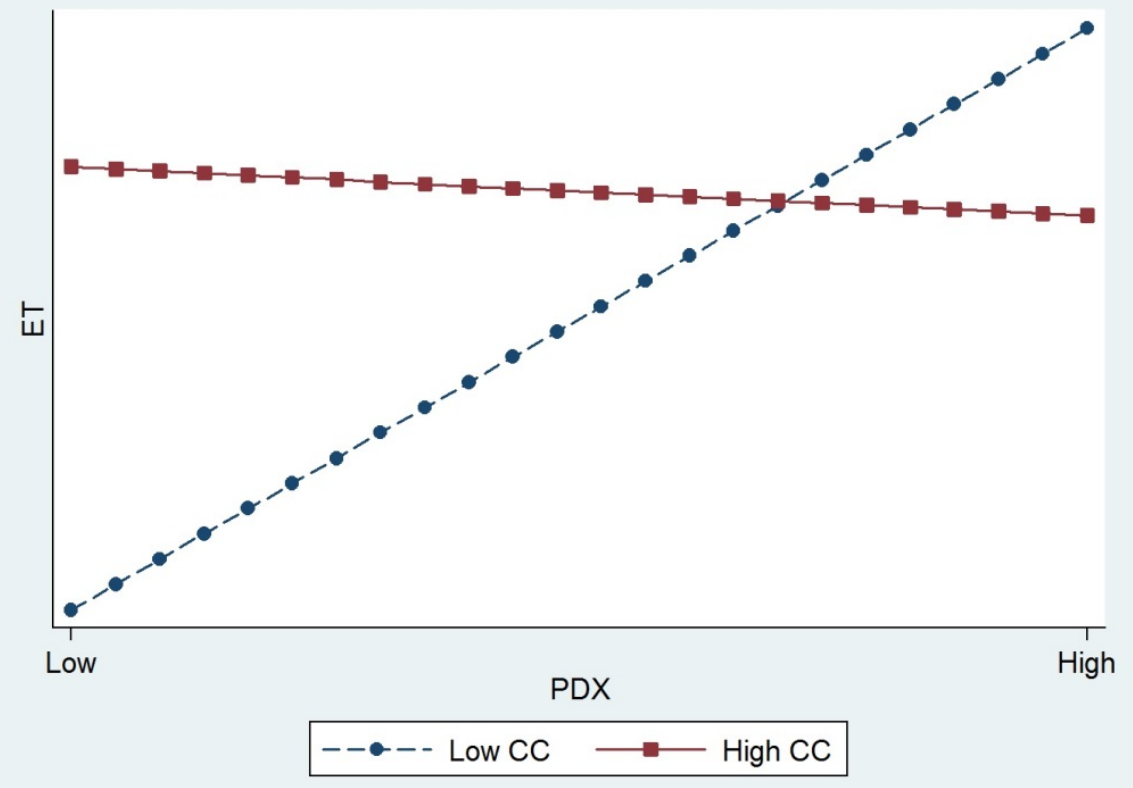

Fig 3. Coopetition capability (CC) as a moderator. 